\title{
INFLUENCE OF THE GEOMETRIC CHARACTERISTICS OF WEDGES ON THE SAFETY OF VRASNA TUNNEL IN EGNATIA HIGHWAY, N. GREECE
}

\author{
Chatziangelou M. ${ }^{1,2}$, and Christaras B. ${ }^{1}$ \\ ${ }^{1}$ Aristotle University of Thessaloniki, School of Geology, 54124 Thessaloniki, \\ christar@geo.auth.gr \\ ${ }^{2} J \&$ P-/ AVAX Co, Amarousiou-Chalandriou 16,15125 Maroussi, Athens, mcha@geo.auth.gr
}

\begin{abstract}
The present paper concerns the influence of the geometric characteristics of the potential wedges on tunnels safety, which are supported by shotcrete and rock bolts, during the excavation of poor and medium quality rock mass, in accordance to RMR classification system. The geological and tectonic data which were used in our estimations were collected in situ during the excavation of Vrasna's tunnel. According to shear test along discontinuities planes, friction angle was considered $21^{\circ}$ on schistosity planes and $35^{\circ}$ on joint planes. Furthermore, no cohesion was taken into account, as the fractures were, more or less, opened. The orientation and spacing of discontinuities were taken into account for estimating tunnel stability, given that they affect the strength and the quality of the rock mass during the construction. The collected data and the obtained, after elaboration, results were correlated statistically and power regressions were determined.
\end{abstract}

Key words: Shotcrete, rock bolts, rock mass quality.

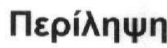

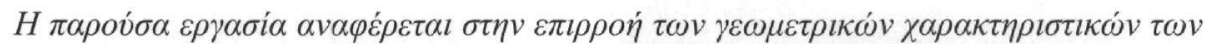

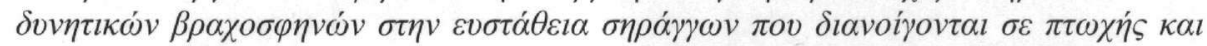

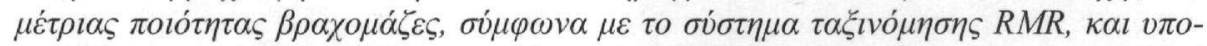

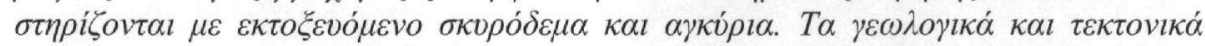

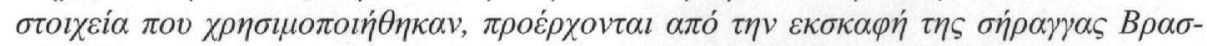

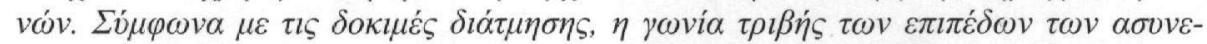

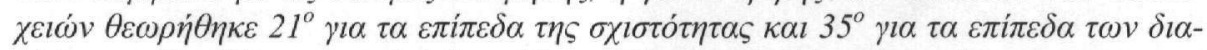

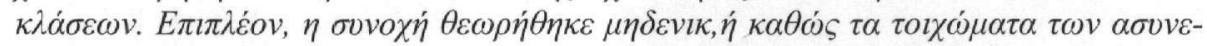

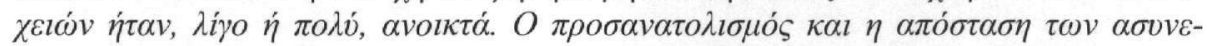

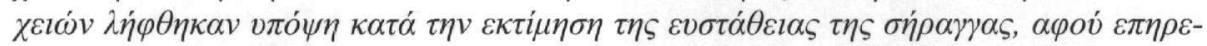

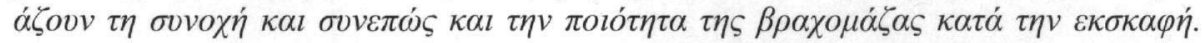

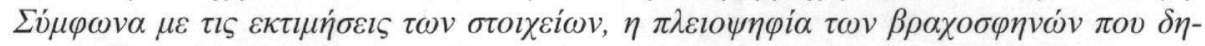

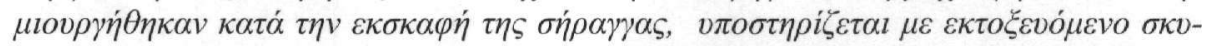


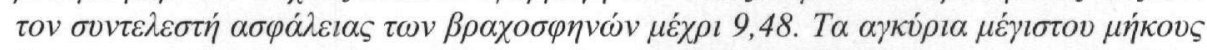

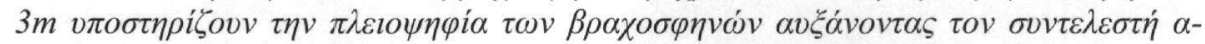

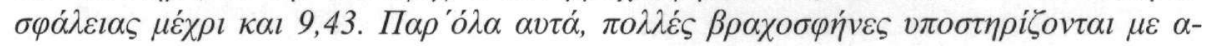




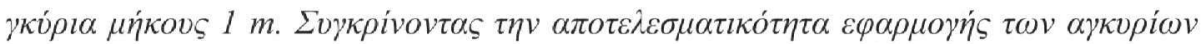

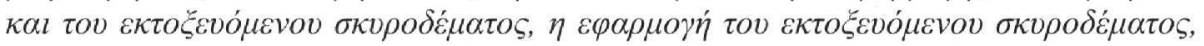

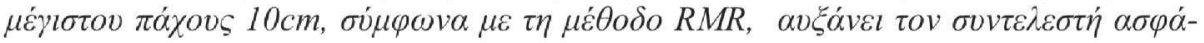

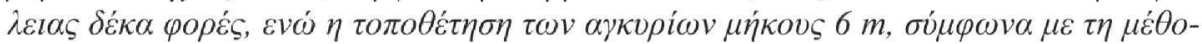

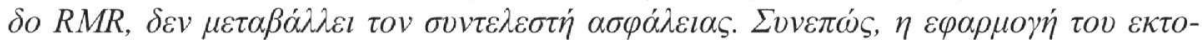

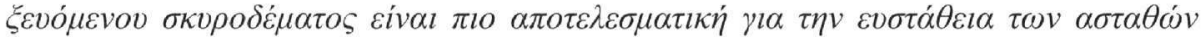

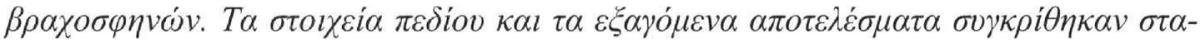

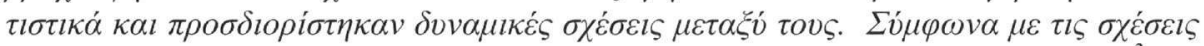

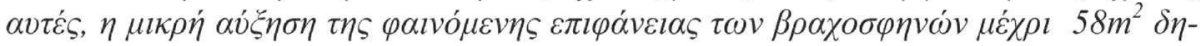

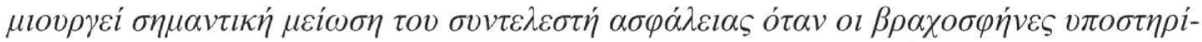

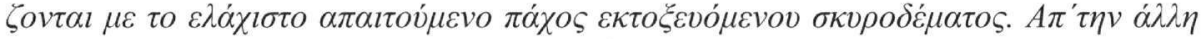

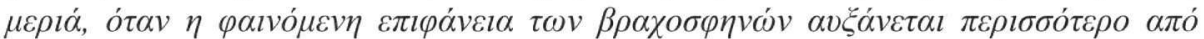

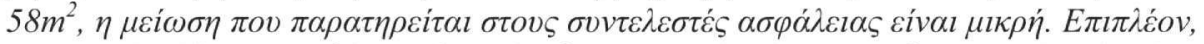

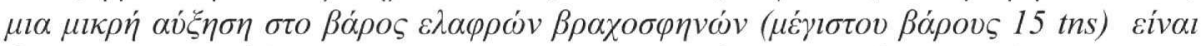

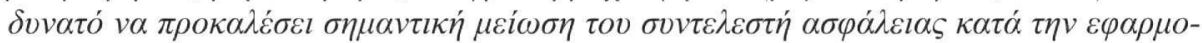

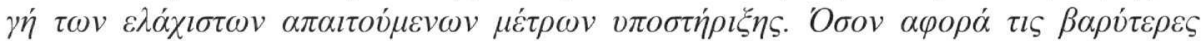

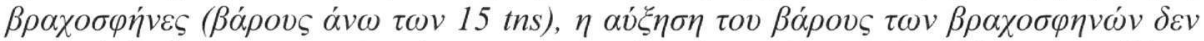

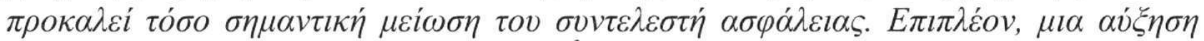

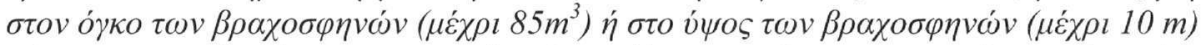

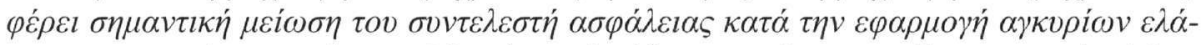

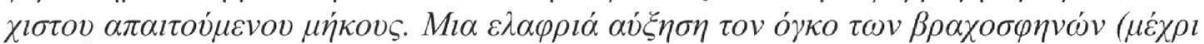

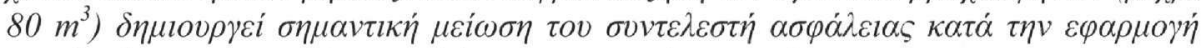

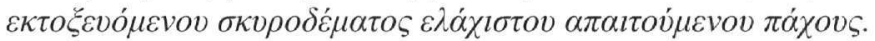

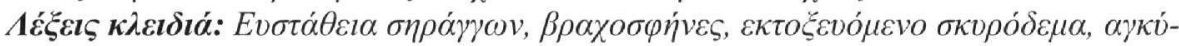

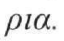

\section{Introduction}

The geological and tectonic data which were used in our elaboration were collected in situ, during Vrasna's tunnel excavation. The Vrasna's tunnel is located in northern Greece, $80 \mathrm{~km}$ to the east of Thessaloniki City. It belongs to the Nymphopetra - Redina's part of Egnatia highway. The tunnel (Fig. 1), which is about $12 \mathrm{~m}$ high, consists of two parallel bores, $140 \mathrm{~m}$ long each, being oriented from the west to the east. A cavern, which is called Drakopetra, is located at the northern part of the tunnel.

\section{Geological settings}

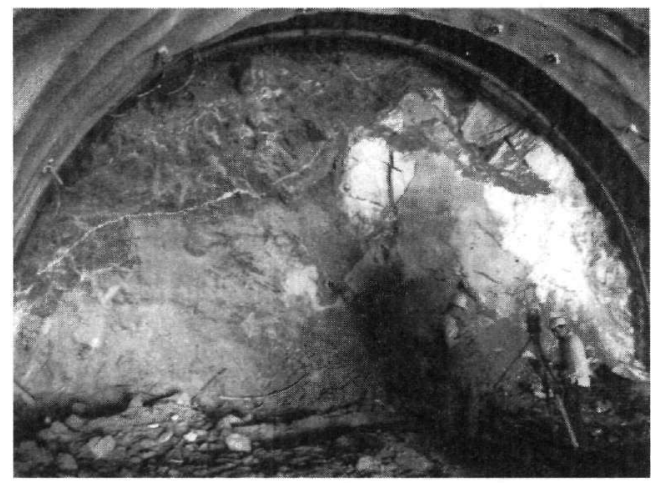

Figure 1 - Medium to poor quality gneiss and good quality marble

The area is geologically located in Serbomacedonian mass, consisting of metamorphic rocks. The wedges in study are placed in cracked rock mass of weathered, brown colored gneiss and karstified marble (Fig. 2) with pegmatitic veins.

The quality of gneiss, which is closely jointed, is generally characterized as poor (IV), changing to very poor (V), near tectonic contacts. The quality of marble, which is widely jointed and less weathered than gneiss, is characterized as good (III) and near tectonic surfaces as poor (IV) (Table 1). The presence of karst phenomena, like the small cavern of Drakopetra, which were observed in marbles, during the excavation, is also taken into ccount on the estimations. 


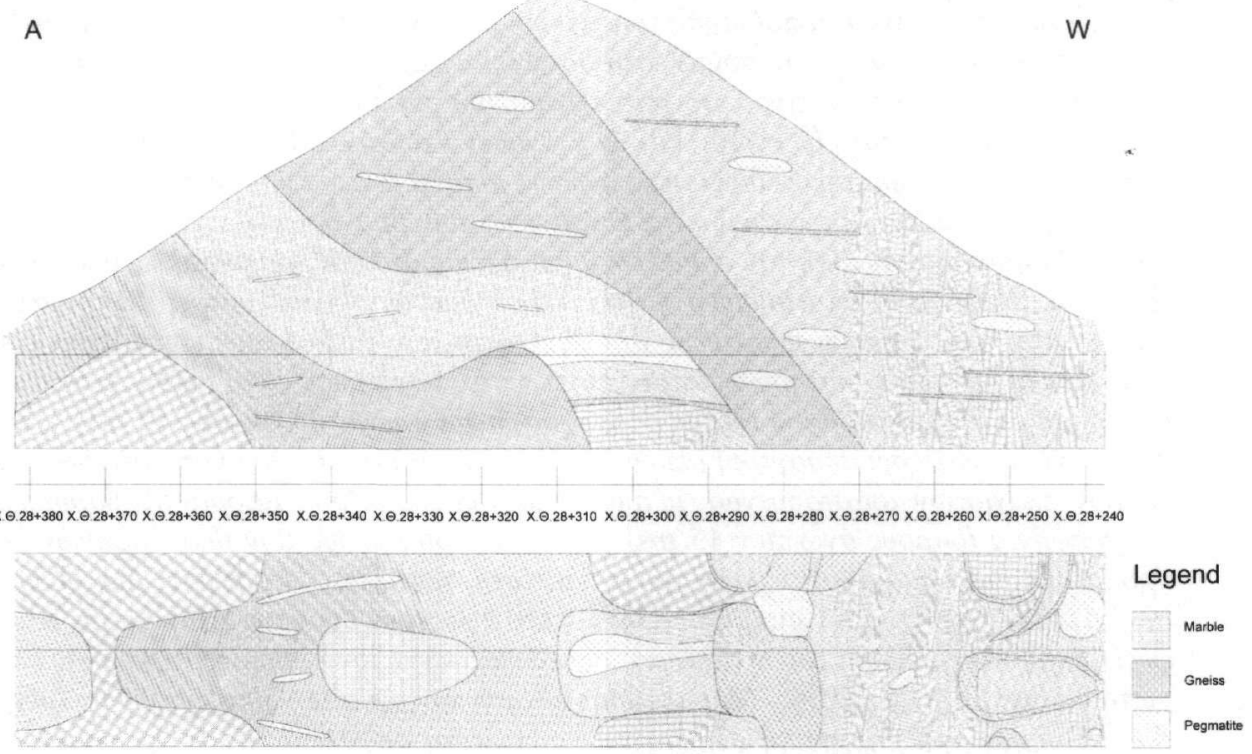

Figure 2 - Geological section along Vrasna tunnel

\section{Support measures}

According to the RMR system, the Vrasna's Tunnel excavation was performed in two stages. Steel ribs, grouted rockbolts and shotcrete were mainly used for the temporary support of the tunnel. The support measures were placed in accordance with RMR system.

So, steel ribs were placed where the rock mass was very poor. Rockbolts were placed, at the very poor parts, mainly around the excavation, in order to strengthen the rock mass. Rockbolts were also used for the support of steel ribs creating more safe conditions. Rockbolts were also placed in good quality rock mass at selected positions, in order to avert the fall of heavy blocks. Thin flexible shotcrete lining was installed to take only a part of the load (Chatziangelou and Christaras 2003).

It is well known that the failure of a rock mass around an underground opening depends upon the in situ stress level and the geotechnical characteristics of the rock mass. In highly stressed rock masses the failure, around the opening, progresses from brittle spalling and slabbing, in the case of massif rocks with few joints, to a more ductile type of failure for heavily jointed rock masses. The presence of many discontinuities provides considerable freedom for individual rock pieces to slide or rotate within the rock mass (Hoek et al. 1995). Failure, involving slip along intersecting discontinuities in a heavily jointed rock mass, is assumed to occur with zero plastic volume change. For this purpose, in shallow tunnels, as the Vrasna tunnel is, the geometry of the discontinuities is considered to be the main instability cause (Christaras et al. 2002), taking also into account that no groundwater is present higher than the construction floor. The stability of the potential wedges in shallow tunnels, and the efficacy of rock bolts and shotcrete, were studied along the Vrasna's tunnel. 


\section{Calculation methodology}

The dip and dip direction of the major joint sets were in situ measured. So, the unsafe potential wedges were determined and the safety factors were calculated resolving the sliding and resistance forces along the sliding surface.

The geometrical characteristics of the wedges were calculated using geometrical analysis, taking into account that the dips between wedges' sides were estimated by the stereo diagram and the length of discontinuities, which is equal to the length of a wedge's edge, was in situ measured.

For our calculations, the strength of marble was estimated as 2,67 Mpa, using point load test. The strength of moderately weathered gneiss was also estimated as $4,34 \mathrm{Mpa}$ and the strength of very weathered parts of gneiss was estimated $0,62 \mathrm{MPa}$. The strength of pegmatite veins was also estimated as $4,45 \mathrm{Mpa}$, using point load test. Friction angle was considered $21^{\circ}$ on schistosity planes and $35^{\circ}$ on joint planes. Furthermore, it was considered that there is no cohesion between discontinuity planes.

Having found out the unsafe potential wedges around the tunnel, the minimum support measures were determined. The estimations concern the length of rock bolts and the shotcrete thickness, as shotcrete and rock bolts can be placed easier and more quickly than other support measures as still ribs are. Actually, the safety factors, of the above wedges being supported by the minimum support measures, were calculated, resolving the sliding and resistance forces along the sliding surface. For our calculations, theoretical thickness of shotcrete usually of $1 \mathrm{~cm}, 2 \mathrm{~cm}$ or $3 \mathrm{~cm}$ and length of rock bolts of $1 \mathrm{~m}, 2 \mathrm{~m}$ or $3 \mathrm{~m}$ were used. The software "UNWEDGE" (Hoek 2000) helped our calculations.

\section{Estimations}

Thirty-seven unstable wedges, heavier than $5 \mathrm{~ns}$, were estimated (Tables 2-5). At the beginning, the position of unstable wedges, the direction and the type of the failure (sliding or falling) were defined around the opening. The mechanical characteristics of the wedges were estimated; weight, volume, apparent face area on the surface excavation.

After that, the increase of safety using the proposed by RMR support measures was calculated. For this reason, the thickness of shotcrete was considered $10 \mathrm{~cm}$ and the length of rock bolts was considered $6 \mathrm{~m}$. The quality of the rock mass, the mechanical characteristics and the geometry of the wedges, the minimum support measures and the related safety factors, are given in Tables 2-5. Taking into account the orientation and the spacing of discontinuities, and the overall ground conditions, the rock bolt spacing was considered to be varied from $1.5 \mathrm{mx} 1.5 \mathrm{~m}$ to $1.5 \mathrm{mx} 1 \mathrm{~m}$ (Bieniawski 1989).

In accordance to our estimations, shotcrete, up to $3 \mathrm{~m}$ thick, can support the majority of the wedges, increasing the safety factor up to 9,88 . Although some of wedges are very heavy, they are effectively supported by $2 \mathrm{~cm}$ or $1 \mathrm{~cm}$ shotcrete as the rockmass is cracked and separated into pieces. Also, the face area of the heavy wedges is too extensive, and the weight is uniformly divided, so as the wedge weight on a significant point is small enough in order to be supported by $2 \mathrm{~cm}$ or $1 \mathrm{~cm}$ shotcrete. The maxinum thickness of shotcrete, which can support successfully the wedges, is $8 \mathrm{~cm}$, although in the most cases, shotcrete $1 \mathrm{~cm}$ thick can effectively support the most wedges. Rockbolts, up to $3 \mathrm{~m}$ long, can also support the most wedges, increasing the safety factor up to 9,43 . Rock bolts $1 \mathrm{~m}$ long, can support the most of these wedges. In some cases of cracked wedges, the rock bolts do not restrain the wedges from sliding, but they are embodied in the rock mass increasing the cohesion. In that cases the length of rock bolts needs to be small, smaller than the wedges apex height, so as not to increase the sliding forces. Five wedges cannot be effectively 


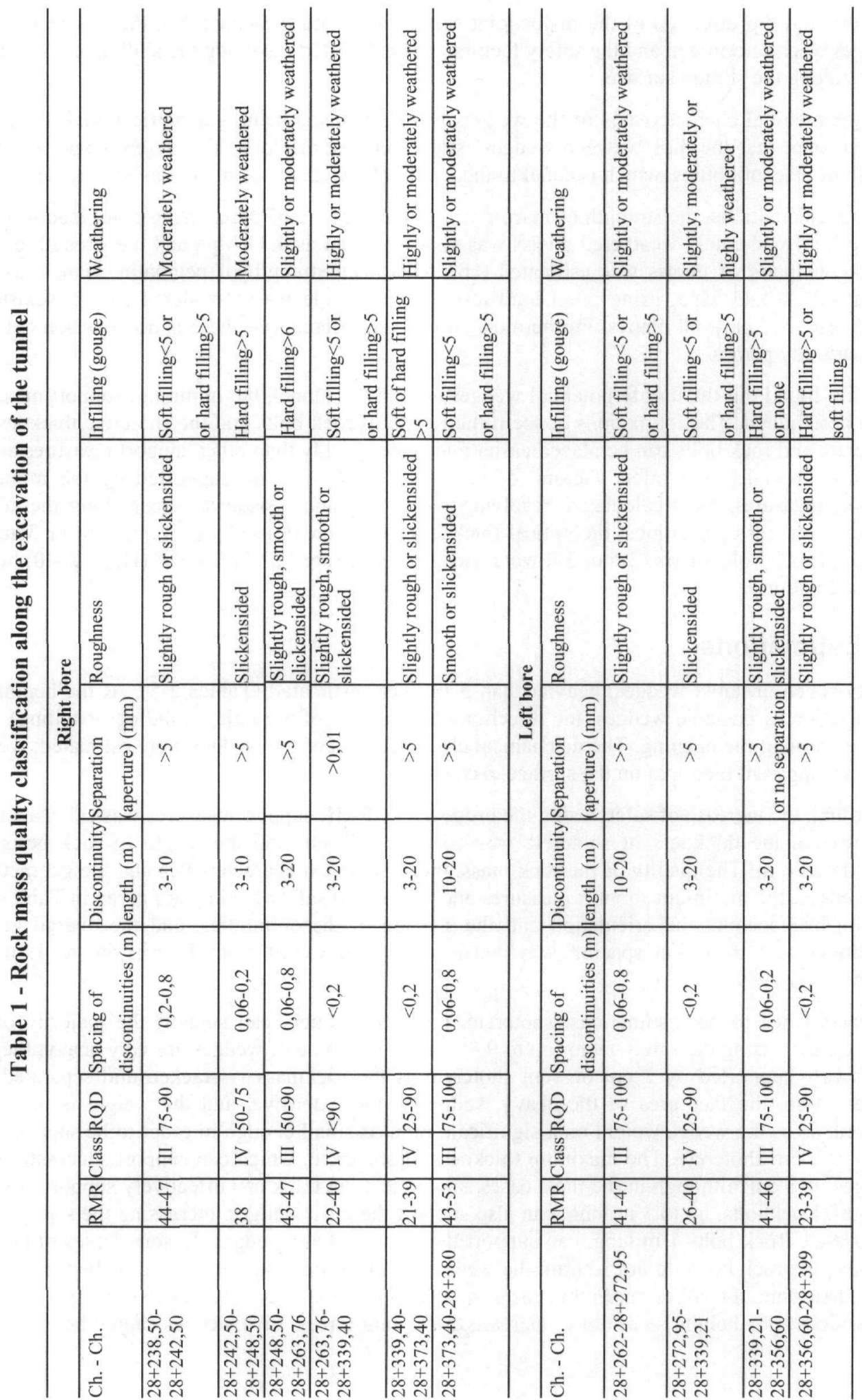


Table 2 - Geometrical characteristics of possible wedges along the left bore of the tunnel

\begin{tabular}{|c|c|c|c|c|c|c|c|c|c|c|}
\hline Ch. - Ch. & $\mathrm{A} / \mathrm{A}$ & Position & $\mathrm{J} 1$ & $\mathrm{~J} 2$ & $\mathrm{~J} 3$ & Sliding & $\begin{array}{l}\text { Weight } \\
\text { (tns) }\end{array}$ & $\begin{array}{c}\text { Face area } \\
\left(\mathrm{m}^{2}\right)\end{array}$ & $\begin{array}{l}\text { Volume } \\
\left(\mathrm{m}^{3}\right)\end{array}$ & $\begin{array}{l}\text { Height } \\
\text { (m) }\end{array}$ \\
\hline $28+262-28+272,95$ & 1 & roof & $204 / 42 \mathrm{~F}$ & $143 / 41 \mathrm{~S}$ & $182 / 77 \mathrm{~J}$ & $\mathrm{~J} 3$ & 137 & 39,97 & 50,67 & 4,38 \\
\hline $28+262-28+272,95$ & 2 & $1 / \mathrm{h}$ wall & $204 / 42 \mathrm{~F}$ & $143 / 41 \mathrm{~S}$ & $182 / 77 \mathrm{~J}$ & $\mathrm{~J} 2$ & 9,2 & 9,54 & 3,39 & 1,13 \\
\hline $28+262-28+272,95$ & 3 & roof & $204 / 42 \mathrm{~F}$ & $143 / 41 \mathrm{~S}$ & $340 / 50 \mathrm{~J}$ & FALL & 19 & 19,19 & 7,04 & 1,26 \\
\hline $28+262-28+272,95$ & 4 & $1 / \mathrm{h}$ wall & $204 / 42 \mathrm{~F}$ & $143 / 41 \mathrm{~S}$ & $340 / 50 \mathrm{~J}$ & $\mathrm{~J} 1 / \mathrm{J} 2$ & 51 & 31 & 19,05 & 2,12 \\
\hline $28+262-28+272,95$ & 5 & $\mathrm{r} / \mathrm{h}$ wall & $204 / 42 \mathrm{~F}$ & $143 / 41 \mathrm{~S}$ & $340 / 50 \mathrm{~J}$ & $\mathrm{~J} 3$ & 99 & 52,17 & 36,7 & 2,49 \\
\hline $28+262-28+272,95$ & 6 & roof & $143 / 41 S$ & $182 / 77 \mathrm{~J}$ & $340 / 50 \mathrm{~J}$ & FALL & 97 & 48,74 & 35,77 & 2,49 \\
\hline $28+262-28+272,95$ & 7 & $1 / \mathrm{h}$ wall & $143 / 41 \mathrm{~S}$ & $182 / 77 \mathrm{~J}$ & $340 / 50 \mathrm{~J}$ & $\mathrm{~J} 1 / \mathrm{J} 2$ & 30 & 27,43 & 11,06 & 1,29 \\
\hline $28+262-28+272,95$ & 8 & $\mathrm{r} / \mathrm{h}$ wall & $143 / 4$ IS & $182 / 77 \mathrm{~J}$ & $340 / 50 \mathrm{~J}$ & $\mathrm{~J} 3$ & 34 & 31,2 & 12,6 & 1,46 \\
\hline $28+272,95-28+339,21$ & 9 & $1 / \mathrm{h}$ wall & $166 / 48 \mathrm{~F}$ & $65 / 44 \mathrm{~J}$ & $338 / 45 \mathrm{~F}$ & $\mathrm{~J} 2$ & 651 & 86,33 & 241,15 & 9,94 \\
\hline $28+272,95-28+339,21$ & 10 & $\mathrm{r} / \mathrm{h}$ wall & $166 / 48 \mathrm{~F}$ & $65 / 44 \mathrm{~J}$ & $338 / 45 \mathrm{~F}$ & $\mathrm{~J} 3 / \mathrm{J} 1$ & 214 & 51,84 & 79,43 & 7,07 \\
\hline $28+272,95-28+339,21$ & 11 & roof & $166 / 48 \mathrm{~F}$ & $65 / 44 \mathrm{~J}$ & $228 / 61 \mathrm{~S}$ & FALL & 286 & 79,91 & 105,84 & 5,36 \\
\hline $28+272,95-28+339,21$ & 12 & $1 / \mathrm{h}$ wall & $166 / 48 \mathrm{~F}$ & $65 / 44 \mathrm{~J}$ & $228 / 61 \mathrm{~S}$ & $\mathrm{~J} 1 / \mathrm{J} 2$ & 11 & 10,17 & 4,02 & 1,23 \\
\hline $28+272,95-28+339,21$ & 13 & $\mathrm{r} / \mathrm{h}$ wall & $166 / 48 \mathrm{~F}$ & $65 / 44 \mathrm{~J}$ & $228 / 61 \mathrm{~S}$ & $\mathrm{~J} 3$ & 24 & 23,92 & 8,73 & 1,44 \\
\hline $28+272,95-28+339,21$ & 14 & roof & $338 / 45 \mathrm{~F}$ & $65 / 44 \mathrm{~J}$ & $228 / 61 \mathrm{~S}$ & FALL & 80 & 47,84 & 29,55 & 2,54 \\
\hline $28+272,95-28+339,21$ & 15 & $1 / h$ wall & $338 / 45 \mathrm{~F}$ & $65 / 44 \mathrm{~J}$ & $228 / 61 \mathrm{~S}$ & 12 & 131 & 51,64 & 48,36 & 3,1 \\
\hline $28+272,95-28+339,21$ & 16 & $\mathrm{r} / \mathrm{h}$ wall & $338 / 45 \mathrm{~F}$ & $65 / 44 \mathrm{~J}$ & $228 / 61 \mathrm{~S}$ & $\mathrm{~J} 1 / \mathrm{J} 3$ & 144 & 65,92 & 53,3 & 3,11 \\
\hline $28+339,21-28+356,6$ & 17 & $\mathrm{r} / \mathrm{h}$ wall & $314 / 51 S$ & $174 / 47 \mathrm{~F}$ & $117 / 58 \mathrm{~F}$ & FALL & 133 & 27,73 & 49,43 & 6,01 \\
\hline $28+339,21-28+356,6$ & 18 & $\mathrm{r} / \mathrm{h}$ wall & $314 / 51 \mathrm{~S}$ & $256 / 40 \mathrm{~S}$ & $117 / 58 \mathrm{~F}$ & $\mathrm{~J} 2$ & 83 & 20,39 & 30,85 & 5,11 \\
\hline $28+356,6-28+399$ & 19 & $1 / h$ roof & $102 / 9 \mathrm{~S}$ & $161 / 66 \mathrm{~J}$ & $95 / 71 \mathrm{~J}$ & $\mathrm{~J} 3$ & 31 & 16,13 & 11,33 & 2,68 \\
\hline $28+356,6-28+399$ & 20 & $\mathrm{r} / \mathrm{h}$ roof & $102 / 9 \mathrm{~S}$ & $161 / 66 \mathrm{~J}$ & $95 / 71 \mathrm{~J}$ & $\mathrm{~J} 2$ & 18 & 12,06 & 6,48 & 2,09 \\
\hline
\end{tabular}

Table 3 - Support of possible wedges along the left bore of the tunnel

\begin{tabular}{|c|c|c|c|c|c|c|c|c|}
\hline Ch. - Ch. & $\mathrm{A} / \mathrm{A}$ & $\mathrm{SF}_{\text {before }}$ & $\begin{array}{l}\text { min.thickness } \\
\text { of shotcrete }(\mathrm{cm})\end{array}$ & $\mathrm{SF}_{\text {shotctele }}$ & $\begin{array}{l}\text { min. length } \\
\text { of bolts (m) }\end{array}$ & $\mathrm{SF}_{\text {bohts }}$ & $\mathrm{Sf}_{\mathrm{gun}-10 \mathrm{~cm}}$ & $S f_{\text {bols }}=6 m$ \\
\hline $28+262-28+272,95$ & 1 & 0,16 & 1 & 1,01 & 2 & 1,11 & 8,67 & 1,49 \\
\hline $28+262-28+272,95$ & 2 & 0,44 & 1 & 8,27 & 1 & 6,27 & 65,58 & 6,27 \\
\hline $28+262-28+272,95$ & 3 & 0 & 1 & 3,57 & 1 & 4,68 & 36,27 & 4,06 \\
\hline $28+262-28+272,95$ & 4 & 0,28 & 1 & 2,89 & 1 & 3,31 & 26,35 & 5,12 \\
\hline $28+262-28+272,95$ & 5 & 0,59 & 1 & 2,07 & 1 & 3,18 & 15,41 & 3,81 \\
\hline $28+262-28+272,95$ & 6 & 0 & 1 & 1,11 & 1 & 1,54 & 11,12 & 2,05 \\
\hline $28+262-28+272,95$ & 7 & 0,44 & 1 & 3,8 & 1 & 5,86 & 34 & 5,86 \\
\hline $28+262-28+272,95$ & 8 & 0,59 & 1 & 3,65 & 1 & 6,3 & 31,16 & 6,29 \\
\hline $28+272,95-28+339,21$ & 9 & 0,73 & 2 & 1,25 & 2 & 1,16 & 3,15 & 1,63 \\
\hline $28+272,95-28+339,21$ & 10 & 0 & 1 & 4,66 & 1 & 6,58 & 41,52 & 14,72 \\
\hline $28+272,95-28+339,21$ & 11 & 0 & 3 & 1,18 & 3 & 1,18 & 3,86 & 1,17 \\
\hline $28+272,95-28+339,21$ & 12 & 0,64 & 1 & 9,88 & 1 & 12,53 & 92,6 & 8,58 \\
\hline $28+272,95-28+339,21$ & 13 & 0,21 & 1 & 3,67 & 1 & 5,04 & 29,81 & 5,49 \\
\hline $28+272,95-28+339,21$ & 14 & 0 & 1 & 1,3 & 1 & 2,12 & 11,97 & 2,74 \\
\hline $28+272,95-28+339,21$ & 15 & 0,73 & 1 & 1,81 & 1 & 2,56 & 11,59 & 3,48 \\
\hline $28+272,95-28+339,21$ & 16 & 0,26 & 1 & 1,24 & 1 & 2,35 & 10,13 & 3,52 \\
\hline $28+339,21-28+356,6$ & 17 & 0 & 7 & 1,08 & 12 & 0,28 & 1,54 & 0,22 \\
\hline $28+339,21-28+356,6$ & 18 & 0,46 & 1 & 1,25 & 2 & 1,21 & 8,36 & 1,48 \\
\hline $28+356,6-28+399$ & 19 & 0,24 & 1 & 2,08 & 1 & 3,22 & 18,66 & 2,59 \\
\hline $28+356,6-28+399$ & 20 & 0,31 & 1 & 2,11 & 1 & 1,66 & 18,31 & 2,5 \\
\hline
\end{tabular}


Table 4 - Geometrical characteristics of possible wedges along the right bore of the tunnel

\begin{tabular}{|c|c|c|c|c|c|c|c|c|c|c|}
\hline Ch. - Ch. & $\mathrm{A} / \mathrm{A}$ & Position & $\mathrm{J} 1$ & $\mathrm{~J} 2$ & $\mathrm{~J} 3$ & Sliding & $\begin{array}{l}\text { Weight } \\
\text { (tns) }\end{array}$ & $\begin{array}{l}\text { Face area } \\
\left(\mathrm{m}^{2}\right)\end{array}$ & $\begin{array}{l}\text { Volume } \\
\left(\mathrm{m}^{3}\right)\end{array}$ & $\begin{array}{l}\text { Height } \\
\text { (m) }\end{array}$ \\
\hline $28+238,50-28+242,50$ & 1 & $1 / \mathrm{h}$ wall & $223 / 49 \mathrm{~J}$ & $353 / 25 \mathrm{~S}$ & $155 / 64 \mathrm{~J}$ & $\mathrm{~J} 1 / \mathrm{J3}$ & 22 & 16,43 & 8,21 . & 1,59 \\
\hline $28+238,50-28+242,50$ & 2 & $\mathrm{r} / \mathrm{h}$ wall & $223 / 49 \mathrm{~J}$ & $353 / 25 \mathrm{~S}$ & $155 / 64 \mathrm{~J}$ & $\mathrm{~J} 2$ & 30 & 22,26 & 11,28 & 1,73 \\
\hline $28+238,50-28+242,50$ & 3 & $1 / \mathrm{h}$ wall & $223 / 49 \mathrm{~J}$ & $353 / 25 \mathrm{~S}$ & $155 / 33 F$ & $J 1 / J 3$ & 30 & 19,34 & 11,27 & 1,9 \\
\hline $28+238,50-28+242,50$ & 4 & $\mathrm{r} / \mathrm{h}$ wall & $223 / 49 \mathrm{~J}$ & $353 / 25 \mathrm{~S}$ & $155 / 33 \mathrm{~F}$ & $\mathrm{~J} 2$ & 60 & 33,81 & 22,14 & 2,22 \\
\hline $28+238,50-28+242,50$ & 5 & $1 / \mathrm{h}$ wall & $223 / 49 \mathrm{~J}$ & $353 / 25 \mathrm{~S}$ & $186 / 70 \mathrm{~J}$ & $\mathrm{~J} 1 / \mathrm{J} 3$ & 20 & 17,44 & 7,29 & 1,32 \\
\hline $28+238,50-28+242,50$ & 6 & $\mathrm{r} / \mathrm{h}$ wall & $223 / 49 \mathrm{~J}$ & $353 / 25 \mathrm{~S}$ & $186 / 70 \mathrm{~J}$ & $\mathrm{~J} 2$ & 20 & 18,94 & 7,57 & 1,31 \\
\hline $28+238,50-28+242,50$ & 7 & $1 / \mathrm{h}$ wall & $155 / 64 \mathrm{~J}$ & $353 / 25 \mathrm{~S}$ & $186 / 70 \mathrm{~J}$ & $\mathbf{J} 3$ & 82 & 32,9 & 30,3 & 3,28 \\
\hline $28+238,50-28+242,50$ & 8 & $1 / \mathrm{h}$ roof & $155 / 64 \mathrm{~J}$ & $223 / 49 \mathrm{~J}$ & $186 / 70 \mathrm{~J}$ & $\mathrm{~J} 3$ & 172 & 23,38 & 66,37 & 10 \\
\hline $28+242,50-28+248,5$ & 9 & $1 / \mathrm{h}$ roof & $178 / 75 \mathrm{~J}$ & $246 / 26 \mathrm{~S}$ & $134 / 42 \mathrm{~F}$ & $\mathrm{~J} 1 / \mathrm{J} 3$ & 105 & 33,38 & 38,92 & 3,94 \\
\hline $28+248,5-28+263,76$ & 10 & roof & $192 / 64 \mathrm{~J}$ & $139 / 32 \mathrm{~F}$ & $356 / 43 \mathrm{~S}$ & FALL & 79 & 51,83 & 29,26 & 2,12 \\
\hline $28+248,5-28+263,76$ & 11 & $1 / \mathrm{h}$ wall & $192 / 64 \mathrm{~J}$ & $139 / 32 \mathrm{~F}$ & $356 / 43 \mathrm{~S}$ & $\mathrm{~J} 1 / \mathrm{J} 3$ & 156 & 72,87 & 57,9 & 2,76 \\
\hline $28+248,5-28+263,76$ & 12 & $\mathrm{r} / \mathrm{h}$ wall & $192 / 64 \mathrm{~J}$ & $139 / 32 \mathrm{~F}$ & $356 / 43 \mathrm{~S}$ & $\mathbf{J} 3$ & 179 & 74,63 & 66,27 & 2,97 \\
\hline $28+263,76-28+339,40$ & 13 & $\mathrm{r} / \mathrm{h}$ wall & $190 / 39 \mathrm{~F}$ & $121 / 50 \mathrm{~S}$ & $359 / 46 \mathrm{~J}$ & FALL & 22 & 12,29 & 8,17 & 2,31 \\
\hline $28+263,76-28+339,40$ & 14 & $\mathrm{r} / \mathrm{h}$ wall & $190 / 39 \mathrm{~F}$ & $121 / 50 \mathrm{~S}$ & $225 / 8 \mathrm{~J}$ & $\mathrm{~J} 1 / \mathrm{J} 3$ & 204 & 49,95 & 75,51 & 5,99 \\
\hline $28+263,76-28+339,40$ & 15 & $\mathrm{r} / \mathrm{h}$ roof & $179 / 63 \mathrm{~F}$ & $121 / 50 \mathrm{~S}$ & $225 / 8 \mathrm{~J}$ & $\mathrm{~J} 1 / \mathrm{J} 3$ & 11 & 10,39 & 4,14 & 1,85 \\
\hline $28+263,76-28+339,40$ & 16 & $1 / \mathrm{h}$ wall & $179 / 63 \mathrm{~F}$ & $121 / 50 \mathrm{~S}$ & $225 / 8 \mathrm{~J}$ & J2 & 103 & 34,38 & 38,11 & 4,44 \\
\hline $28+339,40-28+373,40$ & 17 & $1 / \mathrm{h}$ wall & $153 / 39 \mathrm{~S}$ & $63 / 31 \mathrm{~F}$ & $160 / 72 \mathrm{~F}$ & $\mathrm{~J} 3 / \mathrm{J} 2$ & 992 & 53,56 & 367,31 & 23,19 \\
\hline
\end{tabular}

Table 5 - Support of possible wedges along the right bore of the tunnel

\begin{tabular}{|c|c|c|c|c|c|c|c|c|}
\hline Ch. - Ch. & $\mathrm{A} / \mathrm{A}$ & $\mathrm{SF}_{\text {before }}$ & $\begin{array}{l}\text { min.thickness } \\
\text { of shotcrete }(\mathrm{cm})\end{array}$ & $\mathrm{SF}_{\text {shotcrete }}$ & $\begin{array}{l}\text { min. length } \\
\text { of bolts }(m)\end{array}$ & $\mathrm{SF}_{\text {bolts }}$ & $\mathrm{Sf}_{\mathrm{gun}=10 \mathrm{~cm}}$ & $\mathrm{Sf}_{\text {bolts }-6 \mathrm{~m}}$ \\
\hline $28+238,50-28+242,50$ & 1 & 0,66 & 1 & 6,62 & 1 & 5,1 & 60,95 & 5,84 \\
\hline $28+238,50-28+242,50$ & 2 & 0,82 & 1 & 6,67 & 1 & 6,54 & 59,26 & 7,98 \\
\hline $28+238,50-28+242,50$ & 3 & 0,17 & 1 & 7,09 & 1 & 4,79 & 69,41 & 7,17 \\
\hline $28+238,50-28+242,50$ & 4 & 0,82 & 1 & 4,35 & 1 & 5,11 & 36,08 & 6,58 \\
\hline $28+238,50-28+242,50$ & 5 & 0,61 & 1 & 6,67 & 1 & 7,17 & 61,25 & 7,17 \\
\hline $28+238,50-28+242,50$ & 6 & 0,82 & 1 & 9,17 & 1 & 9,43 & 84,34 & 9,38 \\
\hline $28+238,50-28+242,50$ & 7 & 0,25 & 1 & 1,35 & 1 & 1,59 & 11,23 & 2,05 \\
\hline $28+238,50-28+242,50$ & 8 & 0,25 & 3 & 1,25 & 6 & 0,89 & 3,57 & 0,89 \\
\hline $28+242,50-28+248,5$ & 9 & 0,19 & 1 & 1,12 & 1 & 1,22 & 8,65 & 1,89 \\
\hline $28+248,5-28+263,76$ & 10 & 0 & 1 & 1,48 & 1 & 2,08 & 13,84 & 3,04 \\
\hline $28+248,5-28+263,76$ & 11 & 0,34 & 1 & 1,49 & 1 & 2,31 & 11,06 & 2,86 \\
\hline $28+248,5-28+263,76$ & 12 & 0,41 & 1 & 1,38 & 1 & 1,87 & 10,11 & 2,96 \\
\hline $28+263,76-28+339,40$ & 13 & 0 & 2 & 1,22 & 3 & 0,48 & 6,08 & 0,48 \\
\hline $28+263,76-28+339,40$ & 14 & 0 & 3 & 1,46 & 4 & 0,76 & 4,85 & 0,76 \\
\hline $28+263,76-28+339,40$ & 15 & 0 & 1 & 3,38 & 1 & 1,8 & 33,83 & 1,8 \\
\hline $28+263,76-28+339,40$ & 16 & 0,32 & 2 & 1,61 & 1 & 1,25 & 6,77 & 1,71 \\
\hline $28+339,40-28+373,40$ & 17 & 0 & 8 & 1,11 & 12 & 0,38 & 1,41 & 0,36 \\
\hline
\end{tabular}




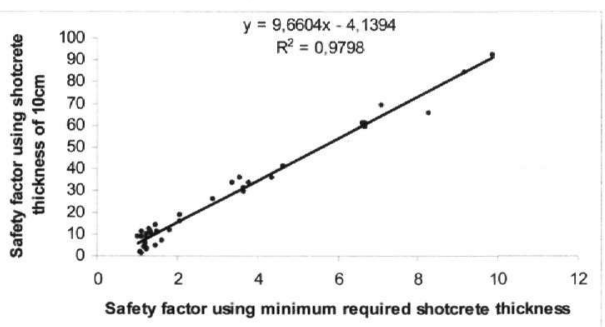

Figure 3 - Correlation between safety factor using the minimum required shotcrete thickness and shotcrete thickness of $10 \mathrm{~cm}$

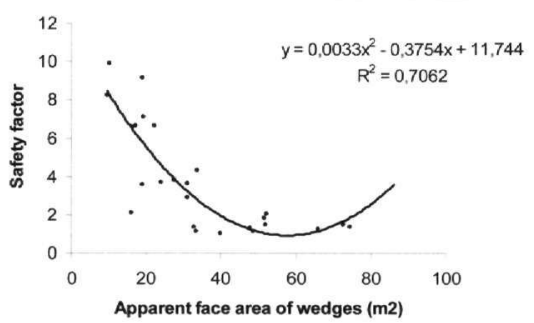

Figure 5 - Correlation between apparent face area of wedges and safety factor of supported wedges with shotcrete of minimum required thickness

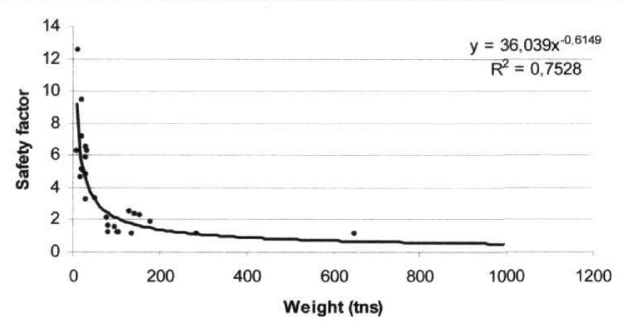

Figure 7 - Correlation between wedges weight and their safety factors after the use of minimum required length of bolts

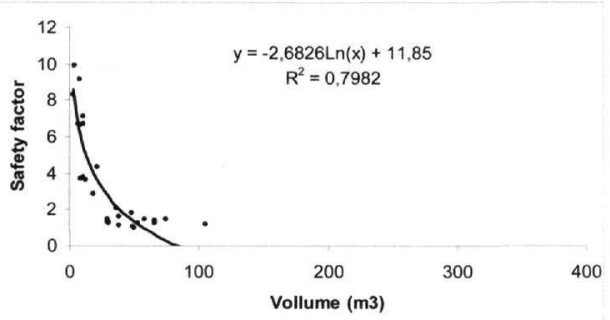

Figure 9 - Correlation between wedge volumes and the safety factors after the use of the minimum required thickness of shotcrete

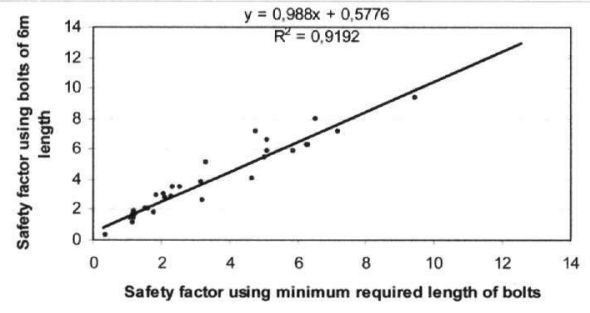

Figure 4 - Correlation between safety factor using the minimum required length of bolts and bolts of $6 \mathrm{~m}$ length

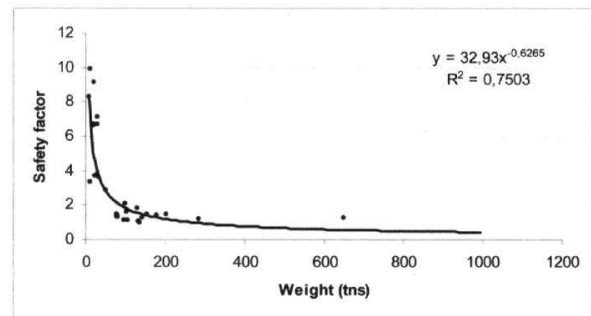

Figure 6 - Correlation between wedges weight and their safety factor after the use of minimum required thickness of shotcrete

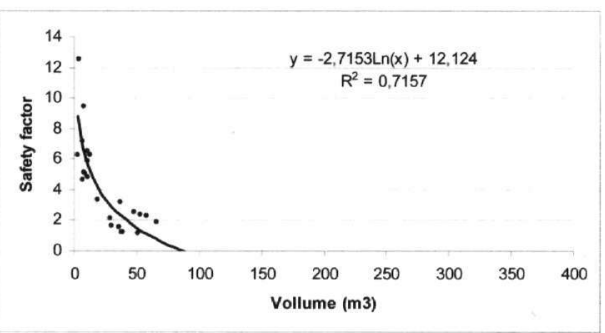

Figure 8 - Correlation between wedge volumes and the safety factors after the use of the minimum required length of bolts

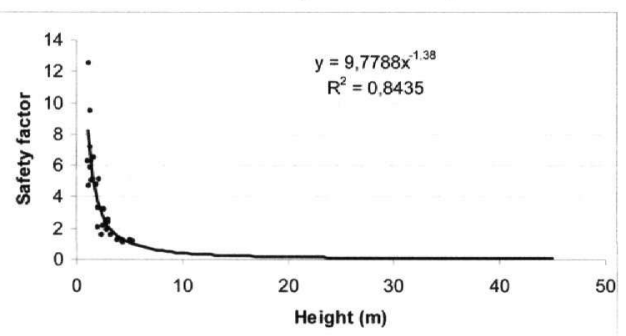

Figure 10 - Correlation between wedge height and the safety factors after the use of the minimum required support with bolts 
supported by rockbolts, although they are effectively supported by shotcrete. Consequently, shotcrete can support with efficacy the unstable wedges better than rock bolts.

As it is observed, there is a linear relation between the safety factor of the wedges, supported by shotcrete of $10 \mathrm{~cm}$ thick and the safety factor of the wedges, supported by shotcrete with the minimum required thickness. According to the above relation, the safety provided by the installation of the proposed by RMR system shotcrete thick, is about ten times the safety provided by the shotcrete with the minimum required thickness installation $\left(\mathrm{SF}_{\text {shot. }=10 \mathrm{~cm}}=9.6604 * \mathrm{SF}_{\text {shotcrete }}{ }^{-}\right.$ $4.1394, \mathrm{R}^{2}=0,97$, Fig. 3). Furthermore, as it is observed, according to the linear relation between the safety factor of the wedges being supported by bolts of $6 \mathrm{~m}$ long and the safety factor of the wedges being supported by bolts, with the minimum required length, the increase of bolts length more than $3 \mathrm{~m}$, doesn't increase the safety $\left(\mathrm{SF}_{\text {bolts }=6 \mathrm{~m}}=0.988^{*} \mathrm{SF}_{\text {bolts }}-0.5776, \mathrm{R}^{2}=0,91\right.$, Fig.4).

The geometrical characteristics of the wedges and the safety factors using the minimum required support measures were correlated statistically and power regressions with significant correlation factors (R) were determined (Figs 5-10):

Apparent face area of wedges (F) and their safety factor (SF), when the wedges are supported by shotcrete with the minimum thickness required $\left(\mathrm{SF}=0.0033 * \mathrm{~F}^{2}-0.3754+11.3744, \mathrm{R}^{2}=0,71\right)$.

Wedge weights (W) and their safety factors (SF) after the use of minimum required thickness of shotcrete $\left(\mathrm{SF}=32.93 \mathrm{~W}^{-0,6265}, \mathrm{R}^{2}=0,75\right)$.

Wedge weights $(\mathrm{W})$ and their safety factors $(\mathrm{SF})$ after the use of minimum required length of bolts $\left(\mathrm{SF}=36.039^{*} \mathrm{~W}^{-0,6149}, \mathrm{R}^{2}=0,75\right)$.

Wedge volumes (V) and the safety factors (SF) after the use of the minimum required length of bolts $\left(\mathrm{SF}=-2.7153 \operatorname{lnSF}+12.124, \mathrm{R}^{2}=0,72\right)$.

Wedge volumes (V) and the safety factors (SF) after the use of the minimum required support by shotcrete $\left(\mathrm{SF}=-2.6826 \ln \mathrm{SF}+11.85, \mathrm{R}^{2}=0,8\right)$.

Wedge height $(\mathrm{H})$ and the safety factors $(\mathrm{SF})$ after the use of the minimum required support by bolts $\left(\mathrm{SF}=9.7788 * \mathrm{SF}^{-1.38}, \mathrm{R}^{2}=0,84\right)$.

\section{Conclusions}

The aim of this paper was the investigation of the workability of shotcrete and rock bolts on tunnels support being excavated in medium and poor quality rock mass. The data for our estimations were collected during the excavation of Vrasna Tunnel.

The final conclusions were based on the estimation of the support of thirty-seven unstable wedges, heavier than $5 \mathrm{tns}$, which were identified along the excavation. The majority of these wedges is supported by shotcrete up to $3 \mathrm{~cm}$ thick, increasing the safety factor up to 9,88 .. Rockbolts, up to $3 \mathrm{~m}$ long, can also support the most wedges, increasing the safety factor up to 9,43 . On the other hand, rock bolts with length of $1 \mathrm{~m}$, can also support the most of these wedges. Comparing the efficacy of rock bolts and shotcrete, there are some wedges that although they are not supported by rock bolts, they are effectively supported by shotcrete. So, the application of shotcrete is more effective than rock bolts, on unstable wedges' safety. The proposed by RMR system thickness of shotcrete is excessive for the safety, as the safety factor is increased ten times. Furthermore, the proposed by RMR system length of rock bolts is also excessive as, it is proved, the increase of the length of rock bolts up to $3 \mathrm{~m}$ does not increase the safety factor.

The elaboration of our results gave power regressions with significant correlations between the geometric-characteristics of the potential wedges and the safety factors, obtained with the shotcrete and rock bolts. According to the above-mentioned relationships, a slight increase of the apparent face area of wedges less than $58 \mathrm{~m}^{2}$ causes a significant decrease of their safety factor (SF) when the wedges are supported by the minimum required shotcrete thickness. On the other hand, the 
safety factors are slightly decreasing when the apparent face area, of the wedges, is more than 58 $\mathrm{m}^{2}$. Furthermore, a slight increase of the wedge weight causes a significant decrease of their safety factors (SF) after the use of minimum required support with shotcrete of wedges weight lower than 15 tns. On the other hand, the safety factors don't decrease significantly by increasing the weight, when wedges are heavier than 15 tns. Furthermore, a slight increase of the wedge weight (lower than 15 tns), causes a significant decrease of their safety factors (SF) when the wedges are supported by the minimum required length of bolts. Nevertheless, when wedges are heavier than 15 tns, the safety factors don't decrease significantly by the weight's increase. A slight increase of the wedges volume, which is lower than $85 \mathrm{~m}^{3}$, causes a significant decrease of the safety factors (SF) after the use of the minimum required length of bolts. Also, a slight increase of the wedges volume which is lower than $80 \mathrm{~m}^{3}$ causes a significant decrease of the safety factors (SF) after the use of the minimum required thickness of shotcrete. A slight increase of the wedges height, which is less than $10 \mathrm{~m}$, causes a significant decrease of the safety factors (SF) after the use of the minimum required length of bolts.

The above estimations show that even if a small strength of support measures, shotcrete or rock bolts, is enough to balance the sliding strength of the wedges in medium and poor rock mass quality having a small percentage of cracking.

\section{References}

Bieniawski, Z.T., 1989. Engineering rock mass classifications, New York: Wiley.

Chatziangelou, M., and Christaras, B., 2003. Shotcrete application effectiveness as support measure at poor quality rock masses, Proc. International Symposium of Industrial Minerals and Building Stones, Konstantinoupolis, Turkey, 745-749pp.

Christaras, B., Chatziangelou, M., Malliaroudakis, Em., and Merkos, S., 2002. Support Capacity of wedges and RMR classification along the Asprovalta tunnel of Egnatia Highway, in n. Greece, $9^{\text {th }}$ Congress of the International Association for Engineering Geology and the Environment, J.L. van Rooy and C.A. Jermy, ISBN No.0-620-28559-1.

Hoek, E., 2000. Practical Rock Engineering, Rotterdam, Balkema.

Hoek, E., Kaiser, P.K., and Bawden, W.E., 1995. Support of underground excavations in hard rocks, Balkema Pbl., Roterdam, 215p. 